\title{
Penerapan Pendekatan Komunikatif Dalam Pembelajaran Bahasa Indonesia untuk Meningkatkan Keterampilan Berbicara Pada Siswa Kelas V.A Di Sekolah Dasar Negeri 008 Tembilahan Hulu
}

\author{
Mariza $^{1}$, Mardiah $^{2}$ \\ ${ }^{1}$ Pendidikan Guru Madrasah Ibtidaiyah, STAI Auliaurrasyidin, Tembilahan Riau, Indonesia \\ ${ }^{2}$ Pendidikan Guru Madrasah Ibtidaiyah, STAI Auliaurrasyidin, Tembilahan Riau, Indonesia \\ *Corresponding author: mariza19212223@gmail.com \\ *Corresponding author: mardiah.mawardi@gmail.com
}

\begin{abstract}
Abstrak
Permasalahan dalam penelitian ini adalah rendahnya keterampilan berbicara siswa pada kelas V. A di Sekolah Dasar Negeri 008 Tembilahan Hulu. Tujuan penelitian ini adalah untuk mengetahui proses penerapan pendekatan komunikatif dalam pembelajaran bahasa Indonesia untuk meningkatkan keterampilan berbicara pada siswa kelas V.A di Sekolah Dasar Negeri 008 Tembilahan Hulu. Untuk mengetahui faktor yang mempengaruhi penerapan pendekatan komunikatif dalam pembelajaran bahasa Indonesia untuk meningkatkan berbicara pada siswa kelas V.A di Sekolah Dasar Negeri 008 Tembilahan Hulu. Metode yang digunakan dalam penelitian ini yaitu dengan menerapkan pendekatan komunikatif dalam pembelajaran bahasa Indonesia. Jenis penelitian ini adalah Penelitian Tindakan Kelas yang dilaksanakan dalam 2 siklus, masing-masing siklus terdiri dari 3 kali pertemuan yang dilakukan dengan 4 tahapan, yaitu: Perencanaan, Pelaksanaan, Observasi dan Refleksi. Teknik dalam pengumpulan data dari hasil Tes, observasi aktivitas siswa dan guru. Hasil penelitian dari analisis data bahwa pada Ketuntasan hasil belajar siswa pada Pra siklus hanya 8 orang $(38,09 \%)$ yang tuntas, pada siklus I meningkat 14 orang $(66,67 \%)$ yang tuntas dan pada siklus II meningkat hingga 21 orang $(100 \%)$ dengan kategori sangat baik, dari data tersebut dapat diketahui bahwa keterampilan berbicara dalam pembelajaran bahasa Indonesia pada siswa kelas V.A di Sekolah Dasar Negeri 008 Tembilahan Hulu Meningkat.
\end{abstract}

Kata kunci: Pendekatan Komunikatif, Keterampilan Berbicara 


\section{PENDAHULUAN}

Pendidikan pada hakikatnya berlangsung dalam suatu proses, Proses itu berupa transformasi nilai-nilai pengetahuan, teknologi dan keterampilan. Penerima proses adalah anak atau siswa yang sedang tumbuh dan berkembang menuju ke arah pendewasaan kepribadian dan penguasaan pengetahuan. Menurut Zakiah Daradjat, "pendidikan adalah usaha atau tindakan untuk membentuk manusia". ${ }^{1}$ Pendidikan dalam pandangan Ahmad D. Marimba, pendidikan adalah "bimbingan yang diberikan sampai mencapai tujuan hidupnya, bagi pendidikan Islam, berlangsung sejak anak dilahirkan sampai mencapai kesempurnaannya yaitu sampai akhir hidupnya. ${ }^{2}$

Secara alamiah kemampuan berbicara sudah dimiliki anak didik sejak masuk ke sekolah. Taraf kemampuan ada yang lancar, sedang dan rendah. Ada siswa yang lancar mengungkapkan keinginannya seperti rasa senang, sakit dan letih. Ada yang mengungkapkan pendapatnya walaupun sederhana.

Menurut Logan dalam Jago Tarigan(1997:162-166), konsep berbicara sebagai sarana berkomunikasi mencakup sembilan hal, yakni :

1. Berbicara dan menyimak sebagai dua kegiatan resiprokal

2. Berbicara sebagai proses individu berkomunikasi

3. Berbicara sebagai ekspresi kreatif

4. Berbicara sebagai tingkah laku

5. Berbicara sebagai tingkah laku yang dipelajari

6. Berbicara distimulasi oleh pengalaman

7. Berbicara sebagai kegiatan memperluas cakrawala

8. Berbicara sebagai kemampuan linguistik dan lingkungan

9. Berbicara sebagai Pancaran kepribadian

Keterampilan berbicara merupakan keterampilan yang mekanistis, artinya semakin sering berlatih, semakin menguasai keterampilan berbicara. Tidak ada orang yang langsung terampil bicara tanpa proses latihan. Berbicara adalah tingkah laku yang harus dipelajari. ${ }^{3}$ Dalam proses pembelajaran di tingkat Sekolah Dasar banyak sekali mata pelajaran-mata pelajaran yang diajarkan.

Mata pelajaran Bahasa Indonesia di sekolah dasar memiliki tugas untuk menanamkan kepada para siswa agar dapat menciptakan siswa yang mampu berbahasa Indonesia dengan baik dan benar terutama dalam berkomunikasi. Dalam pembelajaran bahasa Indonesia yang diajarkan tersebut ada empat keterampilan berbahasa yang harus diajarkan oleh guru yaitu keterampilan menyimak atau mendengarkan, keterampilan berbicara, keterampilan membaca, keterampilan menulis. Keempat

${ }^{1}$ Zakiah Daradjat, Ilmu Pendidikan Islam, (Jakarta: Bumi Aksara, 2006), hlm. 86.

${ }^{2}$ Ahmad D. Marimba, Pengantar Filsafat Pendidikan Islam, (Bandung: Al-Ma'arif, 2002), hlm. 31.

${ }^{3}$ Nur Mustafa dkk, Berbicara, (Pekan Baru: Cendikia Insani, 2006), hlm. 8-11. 
keterampilan di atas sangat berperan penting dalam pembelajaran bahasa Indonesa. Begitu juga dengan keterampilan berbicara. ${ }^{4}$

Dalam mengajar, Guru sangat berperan penting dalam proses pembelajaran begitu juga dalam meningkatkan keterampilan berbicara, Karena guru yang bertugas untuk membimbing siswa agar siswa dapat berkomunikasi dengan baik dan lancar. Pandangan guru terhadap siswa akan menentukan sikap dan perbuatan. Setiap guru tidak selalu mempunyai pandangan yang sama dalam menilai siswa. Hal ini akan mempengaruhi pendekatan yang guru ambil dalam pengajaran. Sebaiknya guru memandang siswa sebagai individu dengan segala perbedaannya, sebab guru haruslah mampu memilih suatu model pembelajaran yang ada, agar dalam proses pembelajaran yang berlangsung dapat membuat siswa terampil dalam berkomunikasi, sesuai dengan tujuan dari pembelajaran bahasa Indonesia. Untuk itu kemampuan guru dalam melakukan pendekatan merupakan dasar penentuan strategi yang akan diwujudkan dengan penentuan metode dalam pembelajaran yang dilakukan. Sedangkan metode merupakan alat yang digunakan dalam pelaksanaan strategi pembelajaran, Jadi pendekatan lebih luas cakupannya dibandingkan dengan strategi. ${ }^{5}$

Salah satu pendekatan yang penting untuk diterapkan oleh guru dalam proses pembelajaran adalah pendekatan komunikatif. Pendekatan komunikatif adalah suatu pendekatan yang bertujuan untuk membuat kompetensi komunikatif sebagai tujuan pembelajaran bahasa, juga mengembangkan prosedur-prosedur bagi pembelajaran empat keterampilan berbahasa (menyimak, membaca, berbicara, dan menulis), mengakui dan menghargai saling ketergantungan bahasa. Pendekatan ini lahir akibat ketidakpuasan para praktisi atau pengajar bahasa atas hasil yang dicapai oleh metode tatabahasa terjemahan, yang hanya mengutamakan penguasaan kaidah tatabahasa, mengesampingkan kemampuan berkomunikasi sebagai bentuk akhir yang diharapkan dari belajar bahasa. ${ }^{6} \mathrm{Jadi}$, pendekatan komunikatif ingin menekankan fungsi bahasa sebagai alat komunikasi dalam proses interaksi antarmanusia. Komunikasi di sini juga bisa berupa komunikasi lisan maupun tertulis.

Pendekatan komunikatif merupakan pendekatan yang berlandaskan pada pemikiran bahwa kemampuan menggunakan bahasa dalam berkomunikasi merupakan tujuan yang harus dicapai dalam pembelajaran bahasa. Jadi pembelajaran yang komunikatif adalah pembelajaran bahasa yang memungkinkan peserta didik memiliki kesempatan yang memadai untuk mengembangkan kebahasaan dan menunjukkan dalam kegiatan berbahasa baik kegiatan produktif maupun reseptif sesuai dengan situasi nyata, bukan situasi buatan yang terlepas dari konteks. ${ }^{7}$

\footnotetext{
${ }^{4}$ Daeng Nurjamal dan Warta Sumirat, Penuntun Perkuliahan Bahasa Indonesia, (Bandung :Alfabeta, 2010), hlm 2-3. hlm. 5.

${ }^{5}$ E. Mulyasa, Standar Kompetensi Sertifikasi Guru, (Bandung: PT Remaja Rosdakarya, 2007),

${ }^{6}$ Iskandarwassid dan Dadang Sunendar, Strategi Pembelajaran Bahasa, (Bandung: Remaja Rosdakarya, 2009), hlm. 55.

7 http://jasonwalkerpanggabean.blogspot.com/2013/09/makalah-pendekatan-komunikatif.html, diakses tanggal 10 Maret 2015.
} 


\section{METODE PENELITIAN}

Jenis penelitian ini adalah penelitian tindakan kelas. Penelitian ini dilaksanakan dalam 2 siklus. Setiap siklus terdiri dari perencanaan, pelaksanaan, Pengamatan dan refleksi.

Dalam menganalisis hasil penelitian, penulis menggunakan teknik deskriptif kualitatif dengan persentase. Data bersifat kualitatif digambarkan dengan kata-kata untuk dipahami dan untuk memperoleh kesimpulan. Sedangkan data kuantitatif yang berwujud angka yang dipresentasikan ke dalam kata-kata atau kalimat, teknik ini disebut deskriptif kualitatif dengan persentase. ${ }^{8}$

Adapun teknik analisa data yang digunakan menggunakan rumus sebagai berikut:

Rumus : $\mathrm{p}=\frac{f}{n} \times 100 \%$

Keterangan :

$\mathrm{F}=$ Frekuensi Hasil Observasi

$\mathrm{N}=$ Number Of Cases ( Jumlah Frekuensi)

$\mathrm{P}=$ Angka Persentase. $^{9}$

Untuk mencari nilai rata-rata menggunakan rumus sebagai berikut :

Rumus : $\bar{X}=\frac{\sum_{i=1}^{n} 1}{n}$

Keterangan :

$\mathrm{X}=$ Rata-rata (baca $\mathrm{x}$ bar)

$\sum \mathrm{X}_{\mathrm{i}} \quad=$ Jumlah seluruh data

$\mathrm{n}=$ Banyaknya data ${ }^{10}$

Hasil masing-masing variabel kemudian dikonsultasikan baik atau tidaknya ditentukan dari persentase dengan klasifikasi sebagai berikut:
a. $81 \%-100 \%$ (Sangat baik).
b. $61 \%-80 \%$ (Baik).
c. $41 \%-60 \%$ (Kurang baik).
d. $21 \%-40 \%$ (Tidak baik).
e. $0 \%-20 \%$ (Sangat tidak baik). ${ }^{11}$

\section{HASIL DAN PEMBAHASAN}

Untuk mengetahui jawaban dari permasalahan ini maka data hasil observasi akan dimasukkan ke dalam tabel rekapitulasi sebagai berikut:

${ }^{8}$ Suharsimi Arikunto, Prosedur Penelitian, Suatu Pendekatan Praktek, (Jakarta : Rineka Cipta, 2002), hlm. 213.

${ }^{9}$ Anas Sugdjiono, Statistik Pendidikan, (Jakarta : PT Raja Grafindo Persada, 2008), hlm 43.

${ }^{10}$ Subana, Moersetyo dan Sudrajat, Statistik Pendidikan, (Bandung : Pustaka Setia, 2000), hlm. 6364.

${ }^{11}$ Riduwan, Belajar Mudah Penelitian untuk Guru, Karyawan dan Peneliti Pemula, (Bandung: Alpabeta, 2005), hlm. 89. 


\section{Prasiklus}

Tabel I

Ketuntasan Hasil Siswa Pada Pra Siklus

\begin{tabular}{cccc}
\hline & Tuntas & \multicolumn{2}{c}{ Tidak tuntas } \\
\hline $\mathrm{F}$ & $\mathrm{P}$ & $\mathrm{F}$ & $\mathrm{P}$ \\
8 & $38,09 \%$ & 13 & $52,38 \%$ \\
\hline
\end{tabular}

Dari penjelasan di atas yang tuntas hanya 8 orang siswa(38,09\%) dan yang tidak tuntas 11 orang siswa(52,38\%). Maka dari itu dilakukan penelitian tindakan kelas.

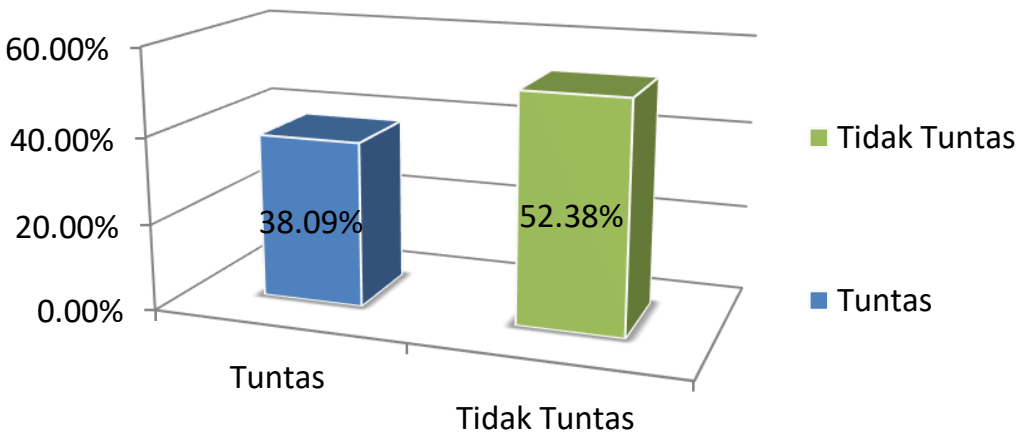

Gambar I

Ketuntasan Siswa dalam Bentuk Diagram Pra Siklus

Siklus 1

Tabel II

Rekapitulasi Hasil Observasi Aktivitas Siswa Siklus I

\begin{tabular}{|c|c|c|c|c|c|c|}
\hline \multirow{2}{*}{ NO } & \multirow{2}{*}{ NAMA SISWA } & \multicolumn{2}{|c|}{$\begin{array}{c}\text { OBSERVASI } \\
\text { PERTEMUAN }\end{array}$} & \multirow{2}{*}{ JUMLAH } & \multirow{2}{*}{$\begin{array}{l}\text { SKOR } \\
\text { IDEAL }\end{array}$} & \multirow{2}{*}{ PERSENTASE } \\
\hline & & 1 & 2 & & & \\
\hline 1 & Agus Setiawan & 3 & 3 & 6 & 8 & $75,0 \%$ \\
\hline 2 & Aji Arya & 2 & 2 & 4 & 8 & $50,0 \%$ \\
\hline 3 & Ambau Bustami & 2 & 3 & 5 & 8 & $62,5 \%$ \\
\hline 4 & Dhea Nur shaura & 3 & 4 & 7 & 8 & $87,5 \%$ \\
\hline 5 & Edsa Alkhumaira & 3 & 3 & 6 & 8 & $75,0 \%$ \\
\hline 6 & Indra Suwandi & 2 & 3 & 5 & 8 & $62,5 \%$ \\
\hline 7 & Iqbal Maulana & 2 & 5 & 7 & 8 & $87,5 \%$ \\
\hline 8 & Khairul Umam & 2 & 4 & 6 & 8 & $75,0 \%$ \\
\hline 9 & Maylisa Yoza Padilla & 3 & 3 & 6 & 8 & $75,0 \%$ \\
\hline 10 & M.Anugrah & 2 & 3 & 5 & 8 & $62,5 \%$ \\
\hline 11 & M.Dayat & 2 & 2 & 4 & 8 & $50,0 \%$ \\
\hline 12 & M.Ziahulhaq & 2 & 3 & 5 & 8 & $62,5 \%$ \\
\hline 13 & Nurhalisa Bella & 2 & 3 & 5 & 8 & $62,5 \%$ \\
\hline 14 & Nurjanah & 2 & 2 & 4 & 8 & $50,0 \%$ \\
\hline 15 & Nursyafikah & 3 & 3 & 6 & 8 & $75,0 \%$ \\
\hline
\end{tabular}


Prodi Pendidikan Guru Madrasah Ibtidaiyah STAI AuliaurrasyidinTembilahan
ISSN: 2443-0021 e-ISSN: 2716-4136

Mariza, Mardiah (2020)

\begin{tabular}{|c|c|c|c|c|c|}
\hline 16 Rahma & 2 & 2 & 4 & 8 & $50,0 \%$ \\
\hline 17 Rendi Wahyu s & 2 & 4 & 6 & 8 & $75,0 \%$ \\
\hline 18 Rani maysarah & 2 & 3 & 5 & 8 & $62,5 \%$ \\
\hline 19 Riyan Rifandi & 1 & 2 & 3 & 8 & $37,5 \%$ \\
\hline 20 Rizal Agus s & 3 & 3 & 6 & 8 & $75,0 \%$ \\
\hline 21 Sopi Nabila Doni & 2 & 4 & 6 & 8 & $75,0 \%$ \\
\hline Jumlah & 47 & 64 & 113 & 168 & $67,26 \%$ \\
\hline
\end{tabular}

Dari data di atas dapat kita cari nilai rata-rata siswa kelas V.A pada saat siklus 1 yaitu dengan rumus :

$$
\bar{X}=\frac{\sum_{i=1}^{n} 1}{n}=\frac{113}{168}=67,26 \%
$$

Sedangkan untuk mengetahui aktivitas siswa selama proses pembelajaran pada siklus 1 yaitu dengan menggunakan rumus :

$$
\mathrm{NR}=\frac{J S}{S M} X 100 \%=\frac{113}{168} \times 100 \%=67,26 \%
$$

Untuk menganalisis penerapan pendekatan komunikatif yaitu dengan menggunakan rumus :

$$
\mathrm{P}=\frac{f}{n} \times 100 \%=\frac{113}{168} \times 100 \%=67,26 \%
$$

Dari ketiga di atas terlihat bahwa hasil dari penerapan pendekatan komunikatif pada siswa yaitu $(67,26 \%)$. Angka ini masih dikatakan cukup. Untuk itu peneliti membuat siklus kedua agar hasil dari penerapan pendekatan komunikatip ini cukup.

\section{Refleksi}

Refleksi dilakukan oleh peneliti dan kolaborator, di mana setelah pembelajaran berlangsung peneliti meminta hasil observasi dari kolaborator. Setelah itu dilakukaan refleksi apa saja yang kurang saat pertemuan satu dan dua pada siklus 1 dengan itu akan dilakukan perbaikan pada siklus 2. Untuk lebih jelas akan dijelaskan refleksi pada pertemuan 1 dan 2 sebagai berikut :

\section{a. Pertemuan 1}

Pada siklus 1 pertemuan 1 dapat kita lihat pada observasi guru dan siswa dan catatan lapangan yaitu

1) Guru lupa mengabsen siswa

2) Guru lupa menyampaikan tujuan pembelajaran

3) Guru menjelaskan materi Masih ada saja yang bermain dan tidak mendengarkan penjelasan guru.

4) Guru memberikan pertanyaan kepada siswa hanya 4 orang yang bertanya selebihnya diam saja. 
5) Guru meminta siswa mempresentasikan cerita hanya 8 orang siswa saja yang berani itu pun masih terbata-bata dan dibimbing dengan guru selebihnya belum bisa.

6) Guru meminta kesimpulan dari materi siswa hanya mengikuti apa saja kata guru belum bisa mengutarakan pendapatnya.

7) Hanya 7 orang siswa yang berani memberikan jawabannya mengenai cerita selebihnya belum berani dan belum paham.

8) Ada 15 orang siswa yang tidak paham dengan tugas yang diberikan guru.

9) Ada beberapa siswa yang bermain-main saat proses pembelajaran.

Solusi untuk mengatasi permasalahan pada siklus 1 pertemuan ke 1 yaitu :

1) Guru harus memperhatikan lagi langkah-langkah pembelajaran

2) Guru harus lebih mengusai materi saat menjelaskn pembelajaran sehingga dengan begitu siswa tidak bermain-main saat prosess pembelajaran

3) Guru harus membimbing siswa saat diminta untuk mempresentasikan cerita sehingga kalimatnya bisa dimengerti dengan baik

4) Guru harus bisa memotivasi siswa sehingga aktif dalam proses pembelajaran dengan begitu diharapkan siswa berani dalam memberikan kesimpulan mengenai materi yang sudah dipelajari

5) Guru harus bisa memberikan gambaran mengenai soal dari materi sehingga siswa berani menjawab pertanyaan dari guru

6) Guru harus lebih memperhatikan siswa saat diminta untuk memprentasikan cerita dengan begitu siswa berani walaupun masih terbata-bata

7) Guru harus memperhatikan siswa sehingga saat menjelaskan materi siswa tidak bermain-main lagi.

\section{b. $\quad$ Pertemuan 2}

Pada siklus 1 pertemuan 2 dapat kita lihat pada observasi guru dan siswa dan catatan lapangan yaitu

1) Guru lupa memberikan motivasi

2) Guru menjelaskan materi siswa masih ada saja bermain

3) Ada 10 orang siswa yang tidak berani dalam bertanya

4) Guru meminta siswa mempresentasikan cerita hanya 11 orang siswa yang tidak berani mempresentasikan cerita walaupun masih terbata-bata.

5) Hanya 10 orang siswa yang berani memberikan kesimpulan dari cerita.

6) Ada 11 orang siswa yang tidak dapat menyampaikan pendapatnya dengan kalimat yang jelas.

7) Ada 9 orang siswa yang tidak paham dengan tugas yang diberikan guru.

Solusi untuk mengatasi permasalahan pada siklus 1 pertemuan ke 2 yaitu :

1) Guru harus memotivasi siswa saat proses pembelajaran

2) Guru harus memperhatikan siswa lagi saat proses pembelajaran sehingga siswa tidak ada lagi bermain-main

3) Guru harus memberikan motivasi lagi sehingga saat proses pembelajaran siswa menjadi aktif untuk bertanya 
4) Guru harus bisa membimbing siswa saat mempresentasikan cerita sehingga dengan begitu siswa berani untuk bercerita serta siswa berani untuk memberikan kesimpulan sehingga dengan begitu siswa menyampaikan kalimatnya dengan baik dan bisa dimengerti.

\section{Siklus 2}

Tabel II

Rekapitulasi Hasil Observasi Siswa Pada Siklus II

\begin{tabular}{|c|c|c|c|c|c|c|}
\hline \multirow[t]{2}{*}{ No } & \multirow[t]{2}{*}{ Nama Siswa } & \multicolumn{2}{|c|}{$\begin{array}{c}\text { Observasi } \\
\text { Pertemuan }\end{array}$} & \multirow[t]{2}{*}{ Jumlah } & \multirow[t]{2}{*}{ Skor Ideal } & \multirow[t]{2}{*}{ Persentase } \\
\hline & & 1 & 2 & & & \\
\hline 1 & Agus Setiawan & 4 & 3 & 7 & 8 & $87,5 \%$ \\
\hline 2 & Aji Arya & 2 & 3 & 5 & 8 & $62,5 \%$ \\
\hline 3 & Ambau Bustami & 3 & 3 & 6 & 8 & $75,0 \%$ \\
\hline 4 & Dhea Nur shaura & 4 & 4 & 8 & 8 & $100,0 \%$ \\
\hline 5 & Edsa Alkhumaira & 3 & 5 & 8 & 8 & $100,0 \%$ \\
\hline 6 & Indra Suwandi & 2 & 4 & 6 & 8 & $75,0 \%$ \\
\hline 7 & Iqbal Maulana & 3 & 5 & 8 & 8 & $100,0 \%$ \\
\hline 8 & Khairul Umam & 3 & 4 & 7 & 8 & $87,5 \%$ \\
\hline 9 & Maylisa Yoza Padilla & 4 & 4 & 8 & 8 & $100,0 \%$ \\
\hline 10 & M.Anugrah H & 3 & 5 & 8 & 8 & $100,0 \%$ \\
\hline 11 & M.Dayat & 3 & 3 & 6 & 8 & $75,0 \%$ \\
\hline 12 & M.Ziahulhaq & 3 & 4 & 7 & 8 & $87,5 \%$ \\
\hline 13 & Nurhalisa Bella & 4 & 4 & 8 & 8 & $100,0 \%$ \\
\hline 14 & Nurjanah & 3 & 3 & 6 & 8 & $75,0 \%$ \\
\hline 15 & Nursyafikah & 3 & 4 & 7 & 8 & $87,5 \%$ \\
\hline 16 & Rahma & 2 & 3 & 5 & 8 & $62,5 \%$ \\
\hline 17 & Rendi Wahyu s & 4 & 4 & 8 & 8 & $100,0 \%$ \\
\hline 18 & Rani maysarah & 3 & 4 & 7 & 8 & $87,5 \%$ \\
\hline 19 & Riyan Rifandi & 2 & 2 & 4 & 8 & $50,0 \%$ \\
\hline 20 & Rizal Agus s & 3 & 4 & 7 & 8 & $87,5 \%$ \\
\hline 21 & Nabila Doni & 4 & 4 & 8 & 8 & $100,0 \%$ \\
\hline & Jumlah & 65 & 79 & 144 & 168 & $85,72 \%$ \\
\hline & PERSENTASE & $77,38 \%$ & 94,05 & & & \\
\hline
\end{tabular}

Dari data di atas dapat kita cari nilai rata-rata siswa kelas V.A pada saat siklus 2 yaitu dengan rumus :

$$
\bar{X}=\frac{\sum_{i=1}^{n} 1}{n}=\frac{144}{168}=85,72 \%
$$

Sedangkan untuk mengetahui aktivitas siswa selama proses pembelajaran pada siklus 2 yaitu dengan menggunakan rumus :

$$
\mathrm{NR}=\frac{J S}{S M} X 100 \%=\frac{144}{168} \times 100 \%=85,72 \%
$$


Untuk menganalisis penerapan pendekatan komunikatif yaitu dengan menggunakan rumus :

$$
\mathrm{P}=\frac{f}{n} \times 100 \%=\frac{144}{168} \times 100 \%=85,72 \%
$$

Dari ketiga di atas terlihat bahwa hasil dari penerapan pendekatan komunikatif pada siswa yaitu (85,72\%). Angka ini sudah dikatakan baik.

\section{Refleksi}

Refleksi dilakukan oleh peneliti dan kolaborator, di mana setelah pembelajaran berlangsung penulis meminta hasil observasi dari kolaborator. Setelah itu dilakukan refleksi apa saja yang kurang saat pertemuan 1 dan dua pada siklus 2. Untuk lebih jelas akan dijelaskan refleksi pada pertemuan 1 dan 2 sebagai berikut :

\section{a. Pertemuan 1}

Pada siklus 2 pertemuan 1 dapat kita lihat pada observasi guru dan siswa dan catatan lapangan yaitu :

1) Guru menjelaskan materi masih ada saja tidak memperhatikan penjelasan guru.

2) Ada 2 orang siswa yang belum berani bertanya selebihnya sudah.

3) Semuanya sudah berani maju kedepan walaupun pengucapannya masih belum tepat.

4) Hanya 4 orang siswa yang tidak berani berbicara saat diminta untuk bertanya.

5) Ada 2 orang siswa yang tidak bisa mengungkapkan maksud dari cerita.

6) Hanya 1 orang siswa yang tidak bisa menceritakan kembali secara benar.

\section{b. Pertemuan 2}

Pada siklus 2 pertemuan 2 dapat kita lihat pada observasi guru dan siswa dan catatan lapangan yaitu :

1) Guru menjelaskan materi hanya 2 orang yang masih bermain dan tidak memperhatikan guru

2) Guru kurang memberikan motivasi

3) Sudah semua siswa berani dalam mempresentasikan cerita walaupun masih terbata-bata dalam menyusun kalimat dan intonasi yang kurang jelas saat bercerita.

Dari observasi diketahui bahwa, guru telah melaksanakan penerapan pendekatan komunikatif dengan baik. Guru meminta siswa bertanya, memberikan kesimpulan, memberikan tugas untuk mencari maksud dari cerita dan memberi tugas untuk menceritakan secara lisan dan siswa sudah mampu berbicara dengan baik walaupun masih ada beberapa siswa yang masih terbata-bata dan malu saat diminta pendapat dan saat mempresentasikan cerita. Sehingga dapat kita lihat bahwa hasil dari siklus dua yaitu bahwa dari 21 siswa semuanya telah memenuhi nilai KKM Serta nilai rata-rata siswa adalah $(85,72 \%)$ dan angka ini telah dikatakan sangat baik. Untuk itu peneliti memutuskan penelitian ini cukup sampai siklus 2 .

\section{Tabel III}


Prodi Pendidikan Guru Madrasah Ibtidaiyah STAI AuliaurrasyidinTembilahan

ISSN: 2443-0021 e-ISSN: 2716-4136 Mariza, Mardiah (2020)

Rekapitulasi Hasil Pra Siklus, Siklus I dan Siklus II Siswa Kelas V.A

\begin{tabular}{|c|c|c|c|c|}
\hline \multirow{2}{*}{ No } & \multirow{2}{*}{ Nama Siswa } & \multicolumn{3}{|c|}{ Nilai } \\
\hline & & Pra siklus & Siklus 1 & Siklus 2 \\
\hline 1. & Agus Setiawan & 45 & 70 & 75 \\
\hline 2. & Aji Arya & 20 & 20 & 70 \\
\hline 3. & Ambau Bustami & 25 & 40 & 70 \\
\hline 4. & Dhea Nur Saura & 80 & 85 & 90 \\
\hline 5. & Edsa Alkhumaira & 75 & 80 & 90 \\
\hline 6. & Indra Suwandi & 30 & 30 & 70 \\
\hline 7. & Iqbal Maulana & 72 & 75 & 85 \\
\hline 8. & Khairul Umam & 60 & 70 & 75 \\
\hline 9. & May Lisa Yoza Padilla & 72 & 75 & 90 \\
\hline 10. & M.Anugrah Haryanto & 70 & 70 & 80 \\
\hline 11. & M.Dayat & 30 & 50 & 70 \\
\hline 12. & M.Ziahulhaq & 60 & 70 & 75 \\
\hline 13. & Nur Halisa Bella & 62 & 70 & 80 \\
\hline 14. & Nurjanah & 40 & 70 & 75 \\
\hline 15. & Nursyafikah & 35 & 50 & 70 \\
\hline 16. & Rahma & 30 & 30 & 72 \\
\hline 17. & Rendi Wahyu Saputra & 70 & 75 & 85 \\
\hline 18. & Rani Maysarah & 70 & 70 & 80 \\
\hline 19. & Riyan Rifandi & 20 & 20 & 70 \\
\hline 20. & Rizal Agus Saputra & 45 & 70 & 70 \\
\hline \multirow[t]{2}{*}{21.} & Sopi Nabila Doni & 75 & 80 & 90 \\
\hline & Jumlah & 1086 & 1315 & 1632 \\
\hline
\end{tabular}

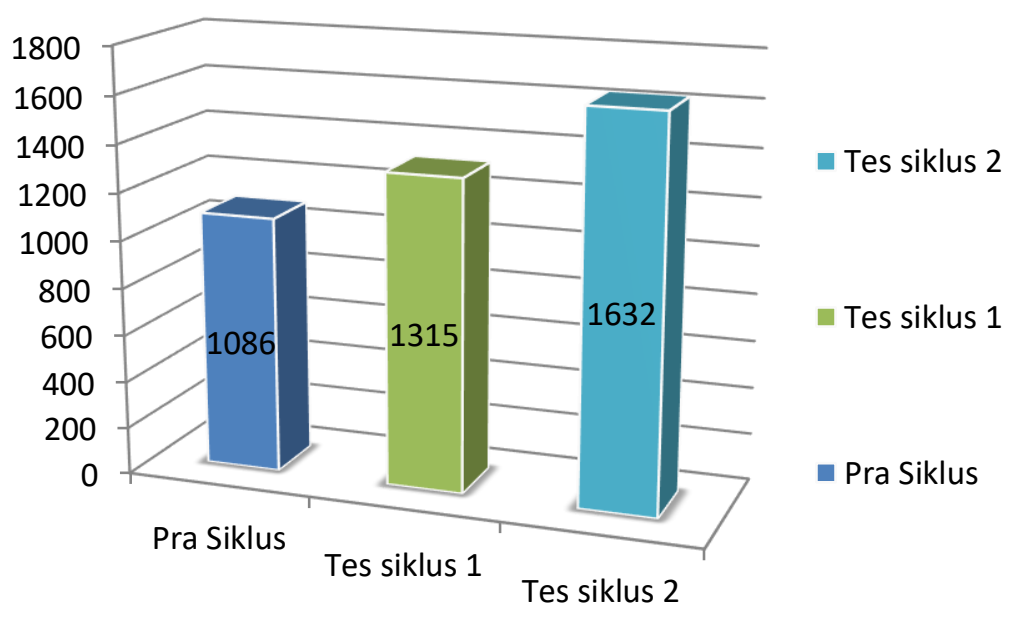

Gambar II Rekapitulasi Pra Siklus, Siklus I dan Siklus II Siswa Kelas V.A

\section{Faktor-faktor yang mempengaruhi peningkatan keterampilan berbicara}

\section{a. Faktor Internal}

1) Minat adalah suatu rasa lebih suka dan rasa keterikatan pada suatu hal atau aktivitas, tanpa ada yang menyuruh. ${ }^{12}$ Dari hasil penelitian saat proses pembelajaran peneliti melihat siswa yang minatnya lebih besar itu lebih aktif

${ }^{12}$ Slameto, Belajar \& Faktor-Faktor Yang Mempengaruhi, (Jakarta: Rineka Cipta, 2013), hlm 180. 
dari pada yang diam. Contohnya saat peneliti memberikan kesempatan untuk bertanya, menjawab, mempresentasikan cerita dan mengeluarkan pendapat. Siswa tidak takut lagi dalam mengeluarkan pendapatnya.

2) Mengetahui dan mengerti ini merupakan kebutuhan manusia untuk memuaskan rasa ingin tahunya, untuk mendapatkan pengetahua, untuk mendapatkan keterangan-keterangan, dan untuk mengerti sesuatu. ${ }^{13}$ Dari penelitian saat proses pembelajaran, peneliti melihat siswa yang pengetahuan dan mengerti itu lebih tinggi mendapatkan nilai. Contohnya saat peneliti meminta siswa untuk mempresentasikan cerita secara lisan dengan pengetahuan dan mengerti saat proses pembelajaran siswa dapat menceritakan dengan baik dan tepat serta dengan intonasi yang jelas.

3) Kelengkapan alat pengucap, dengan lengkapnya alat pengucap siswa sehingga artikulas, intonasi yang diucapkan siswa dapat terdengar dengan jelas. Contohnya saat siswa diminta untuk bertanya, menjawab dan bercerita sudah terdengar dengan jelas.

\section{b. Faktor Eksternal}

1) Motivasi, motivasi adalah dorongan yang diberikan oleh orang lain. Seperti peneliti lakukan sebelum proses pembelajaran berlangsung yang mana peneliti lakukan yaitu membuat siswa percaya diri dan semangat dalam belajar. Contohnya peneliti lakukan membuat permainan dan bernyanyi yang bersangkutan dengan pembelajaran. Sehingga dengan begitu membuat siswa semangat dan memperhatikan penjelasan materi dalam proses pembelajaran.

2) Tujuan pembelajaran, tujuan pembelajaran adalah pernyataan mengenai keterampilan atau konsep yang diharapkan dapat dikuasai oleh siswa pada akhir proses pembelajaran. Contohnya saat peneliti menyampaikan materi bahasa Indonesia mengenai mengidentifikasi unsur cerita (tokoh, tema, latar dan amanat), maka tujuan dari pembelajaran yang harus tercapai oleh siswa yaitu siswa mampu menjawab pertanyaan, menceritakan kembali dan menjelaskan amanat yang terkandung dalam cerpen anak-anak.

3) Nilai, dari penelitian yang dilakukan saat proses pembelajaran berlangsung, nilai adalah suatu hal yang berkaitan dengan berhasil dan tidaknya siswa dalam proses pembelajaran. Saat proses pembelajaran berlangsung peneliti memberikan nilai bertingkat karna siswa yang aktif, dan benar dalam menjawab pertanyaan, bertanya dan saat mempresntasikan cerita akan mendapatkan nilai tinggi yang sesuai dengan kemampuan masing-masing siswa, dibandingkan dengan siswa yang diam saja, maka dengan begitu peneliti bisa mengetahui sampai kemana kemampuan siswa dalam belajar dan dengan memberikan nilai tinggi membuat semua siswa lebih aktif lagi dalam proses pembelajaran.

\footnotetext{
${ }^{13}$ Slameto, ibid., hlm. 172.
} 
4) Media, dengan adanya media yang peneliti gunakan saat proses pembelajaran membuat siswa tertarik dengan pembelajaran yang akan disampaikan oleh peneliti. Contohnya tentang Cerita Harta Yang Terpendam. Maka peneliti lakukan yaitu memperlihatkan kepada siswa gambar apa dan tentang apa yang diceritakan melalui gambar. Dengan begitu timbullah minat dan ketertarikkan siswa untuk mengetahui maksud dari media yang diperlihatkan kepada siswa.

\section{KESIMPULAN DAN SARAN}

Berdasarkan hasil analisis data yang telah peneliti lakukan, maka dapat disimpulkan bahwa terjadi peningkatan setelah penerapan pendekatan komunikatif dalam pembelajaran bahasa Indonesia untuk meningkatkan keterampilan berbicara pada siswa kelas V.A di Sekolah Dasar Negeri 008 Tembilahan Hulu. Observasi mengenai keterampilan berbicara yaitu dilihat dari hasil pra siklus terdapat 8 orang yang tuntas $(38,09 \%)$ dan yang tidak tuntas berjumlah 13 orang $(52,38 \%)$. Keterampilan berbicara pada siklus I yaitu terdapat 15 orang siswa yang tuntas $(66,67 \%)$, dan 7 orang siswa yang tidak tuntas $(33,33 \%)$ dan observasi mengenai keterampilan berbicara pada siklus II yaitu semua siswa sudah berhasil meningkatkan keterampilan berbicara dalam penerapan pendekatan komunikatif pada mata pelajaran Bahasa Indonesia dengan nilai akhir siklus II pertemuan II yaitu $(85,75 \%)$ dengan kategori sangat baik. Faktor-faktor yang mempengaruhi peningkatan keterampilan berbicara adalaha sebagai berikut: Faktor Internal (Minat, Mengetahui dan mengerti, Kelengkapan alat pengucap). Faktor Eksternal (Motivasi, tujuan pembelajaran, Nilai, Media). Untuk peneliti selanjutnya agar dapat mengembangkan dari penelitian yang sudah ada dengan pendekatan yg sama dan lebih memantapkan dari kekurangan penelitian ini.

\section{DAFTAR PUSTAKA}

Sugiyono 2011, Metode Penelitian Kuantitatif, Kualitatif dan $R \& D$, Bandung, Alfabeta.

Ahmad D. Marimba, 2002, Pengantar Filsafat Pendidikan Islam, Bandung: Al-Ma'arif. Anas Sugdijono, 2008, Statistik Pendidikan, Jakarta: Raja Grafindo Persada.

Daeng Nurjamal dan Warta Sumirat, 2010, penuntun Perkuliahan Bahasa Indonesia, Bandung : Alfabeta.

E. Mulyasa, 2007, Standar Kompetensi Sertifikasi Guru, Bandung: Remaja Rosdakarya. Iskandarwassid dan Dadang Sunendar, 2009, Strategi Pembelajaran Bahasa, Bandung:

Remaja Rosdakarya.

Nur Mustafa dkk, 2006, Berbicara, Pekan Baru: Cendikia Insani..

Riduwan, 2005, Belajar Mudah Penelitian untuk Guru, Karyawan dan Peneliti Pemula, Bandung: Alpabeta.

Slameto, 2013, Belajar \& Faktor-Faktor Yang Mempengaruhi, Jakarta : Rineka Cipta. Subana, Moersetyo dan Sudrajat, 2000, Statistik Pendidikan, Bandung: Pusta Setia.

Suharsimi Arikunto, 2002, Prosedur Penelitian, Suatu Pendekatan Praktek, Jakarta: Rineka Cipta. 
Zakiah Daradjat, 2006, Ilmu Pendidikan Islam, Jakarta: Bumi Aksara.

http:/ /jason walke rpanggabean .blogspot.com/ 2013/09/makalah - pendekatan-

komunikatif.html, diakses tanggal 10 Maret 2015 